\title{
Leprosy patients quality of life: a scoping review*
}

\author{
Qualidade de vida de pacientes com hanseníase: uma revisão de escopo \\ Calidad de vida de los pacientes con lepra: una revisión de alcance
}

How to cite this article:

Barcelos RMFM, Sousa GS, Almeida MV, Palacio FGL, Gaíva MAM, Ferreira SMB. Leprosy patients quality of life: a scoping review. Rev Esc Enferm USP. 2021;55:e20200357. DOI: https://doi.org/10.1590/1980-220X-REEUSP-2020-0357

\section{Raissa Mariah Ferraz Moreira Barcelos ${ }^{1}$ \\ Gutembergue Santos de Sousa ${ }^{1}$ \\ D Michelle Veiga de Almeida ${ }^{1}$ \\ D Fabiana Gulin Longhi Palacio ${ }^{2}$ \\ D Maria Aparecida Munhoz Gaíva ${ }^{1}$ \\ iD Silvana Margarida Benevides Ferreira ${ }^{1}$}

* Extracted from dissertation: "Qualidade de vida em hanseníase: scoping review”, Programa de pós-graduação da Faculdade de enfermagem, Universidade Federal de Mato Grosso, 2019.

${ }^{1}$ Universidade Federal de Mato Grosso, Programa de Pós-Graduação em Enfermagem, Cuiabá, MT, Brazil.

${ }^{2}$ Universidade de São Paulo, Biblioteca da Escola de Enfermagem, São Paulo, SP, Brazil.

\section{ABSTRACT}

Objective: To explore the scientific evidence regarding the leprosy patients quality of life. Method: Scoping review according to the Joanna Briggs Institute methodology, with articles indexed in PubMed, Cochrane, LILACS, Embase, CINAHL, Scopus, Web of Science, PsyINFO, INFOLEP, and Google Scholar databases, published in full in Portuguese, English, or Spanish. Results: Seventy-four studies were identified, with 71 of quantitative approach and 3 with a mixed method. There was a predominance of studies published in Brazil (58.1\%), with an adult population, (97.3\%) and recruited in reference centers for the treatment of leprosy $(52.7 \%)$. There was greater use of the WHOQOL-bref (50\%) and SF-36 (18.9\%) instruments to assess quality of life. The study showed that the greatest impairment in quality of life was related to the delay in the diagnosis of the disease, to leprosy reactions, physical disabilities, neuropathic pain, and stigma. Conclusion: Most studies were developed in endemic countries, with adults, and based on observational studies, and the worst scores obtained were associated with physical domain impairment.

\section{DESCRIPTORS}

Leprosy; Quality of Life; Neglected Diseases; Review. 


\section{INTRODUCTION}

Leprosy is a neglected and stigmatizing tropical disease. Advances in treatment and the implementation of strategies for its control have significantly reduced its prevalence worldwide. However, its magnitude and high disabling power keep it as a public health problem in 123 countries $^{(1)}$.

In 2019, 202,185 new cases of leprosy were reported worldwide, with 14,981 (7.4\%) of these being detected in children under 15 years of age. In addition, of the total number of new cases registered in the world in that same year, 29,936 (93\%) occurred in the region of the Americas and 27,863 in Brazil, a figure that places this country as the only one on the continent that remains endemic for the disease ${ }^{(1)}$.

Given the epidemiological scenario of leprosy, which is a condition that represents a priority problem for the health of the individual and his family, there are other challenges to be overcome, such as stigma, social reintegration, and improvement in the patients' quality of life scores ${ }^{(2-5)}$.

Leprosy can affect the skin and peripheral nerves and cause deformities and physical incapacities with relevant social $^{(3)}$, emotional ${ }^{(4)}$, and psychological ${ }^{(5)}$ impact and, consequently, impairment in the Quality of Life (QoL) of patients affected by the disease ${ }^{(2,6-8)}$.

According to the World Health Organization (WHO), QoL is defined as the individual's perception of their position in life, in the context of the culture and value systems in which they live and in relation to their goals, expectations, standards, and concerns ${ }^{(9)}$.

The health area, by providing a debate on QoL from the perspective of patient's health, consolidates it as an important thematic axis to be considered both in the context of care practices and in the production of knowledge and public policies. This discussion shows how important it is to assess the impact of diseases on the population's living conditions, contributing to the overcoming of the biomedical model with reference to socioeconomic, psychological, cultural aspects, and actions for health promotion, treatment, and rehabilitation ${ }^{(10-12)}$.

Quality of life in the health field can be assessed with general or specific instruments. The instruments considered general cover different clinical conditions, allowing the analysis of the disease involvement in the patient's life, and are indicated to assess larger groups. The specific ones, in their turn, measure the QoL of a given disease in a one-time manner ${ }^{(10,13-14)}$.

Analyzing QoL through validated instruments with reliable psychometric properties allows measuring to what extent the condition relates to daily life, identifying what is not visible, such as feelings of pain and anguish ${ }^{(14)}$.

Leprosy patients may have compromised QoL, with damage mainly in the physical and psychological domains. The physical domain has a direct predominance in the patient's work and daily activities, and this can lead to segregation, isolation, and depressive manifestations, while the psychological domain depicts the way patients see themselves and relate to the interactional aspects in the environment where they live $e^{(2,6-7,15-26)}$.

In recent years, studies on the assessment of QoL in the health area have become more relevant in the scientific community as they, in addition to data from biomedical measures, also included psychosocial issues, which helped to better measure QoL. This turns to be a relevant process, because the medical condition brings personal and social consequences, requiring the expansion of public policies aimed at strengthening the quality of care provided, especially aspects related to the QoL of these patients and their families ${ }^{(12,27-28)}$.

Although there is significant scientific production on leprosy, studies assessing the QoL of patients with the disease still need to be expanded, as they are essential for directing attention and health policies. In this regard, the present study aimed to explore the scientific evidence related to the assessment of the quality of life of leprosy patients aiming to characterize the scientific production, find the instruments and domains used in this assessment, synthesize the main findings, as well as identify gaps in knowledge.

\section{METHOD}

\section{Design of Study}

The scoping review was conducted according to the methodology by the Joanna Briggs Institute (JBI) ${ }^{(29)}$, which allows mapping the main concepts, clarifying research areas, and identifying knowledge gaps. The methodological procedures of this method are based on five steps: 1 -Identification of the research question; 2 -Identification of relevant studies; 3 - Study selection; 4 - Data tabulation; 5 - Conference, summary, and reporting of results ${ }^{(29)}$.

\section{Population}

The mnemonic PCC (Population, Concept, and Context) ${ }^{(29)}$ was adopted, with the defintions of $\mathrm{P}$ - studies including patients of any age and sex, with a current or previous diagnosis of leprosy; C - since the terms 'quality of life' (QoL) and 'health-related quality of life' (HRQoL) are commonly used interchangeably in the literature ${ }^{(30)}$, to avoid unnecessary exclusion of relevant studies, we considered all studies that aimed to assess QoL or HRQL; C - any environment where the study was developed, such as community, health units of primary, secondary, and tertiary levels, reference in leprosy treatment, or social environments such as former colonies of patients living with the disease. Then, the following research question was elaborated: what evidence is available in the literature on the QoL of patients with leprosy? In addition, more specifically: what are the characteristics of scientific productions, the instruments and domains used in the assessment of these patients, and the gaps in the knowledge produced?

\section{Selection Criteria}

Relevant studies were selected based on the following eligibility criteria: primary studies with a quantitative/qualitative approach or with a mixed method (quali-quantitative); and 
published with full text in Portuguese, English, or Spanish, from the beginning of the first publications available in the databases until October 19,2020. Those who did not answer the research question or who evaluated and/or reported the results of only one domain of QoL were excluded.

\section{Definition of Search and Inclusion Strategy}

The identification of relevant studies was developed in three stages, starting in July 2018 and updated in October 2020.

A preliminary step of research was taken in the PubMed and Lilacs databases with the descriptors "quality of life" AND "leprosy", to identify primary studies on the topic and possible descriptors in the titles and abstracts, to expand the research.

In the next step, the search strategy was developed according to the specificity of each database (Chart 1): MEDLINE/PubMed, Cochrane Central, LILACS, Embase, CINAHL, Scopus, Web of Science, PsyINFO, INFOLEP, and Google scholar. Finally, in the third step, the reference lists of the studies selected were accessed for additional research. The Mendeley Desktop software, version 1.19.2, was used as a reference manager.

The process of selection and inclusion of studies (title, abstract and full reading) was carried out by two independent reviewers and by a third one when there was disagreement among peers.

\section{Data Extraction}

An adaptation of a standardized questionnaire ${ }^{(31)}$ was used to extract data regarding the identification of the publication (title, authors, country, language), as well as methodological characteristics of the studies (research design, study objectives, population characterization, results, conclusions), criteria used to assess QoL (instruments used and QL domains evaluated), and significant results regarding the impact of the disease on QoL (variables associated with lower QoL indexes and recommendations).

\section{Data Analysis and Treatment}

The selection process of the studies included in this review is presented in the flowchart of preferred report items for systematic reviews and meta-analyses (PRISMA) ${ }^{(32)}$. The findings on the leprosy patients QoL in each publication were identified and extracted considering the objectives of the review, being organized in tables and charts and synthesized in a narrative form.

As this is a systematic scoping review, and according to the adopted methodology, it is exempt from assessment of the methodological quality of the included studies ${ }^{(29)}$.

\section{Ethical AspeCts}

Regarding the ethical aspect, the reliability and fidelity of the information contained in the selected publications were ensured through proper referencing and rigor in data treatment and presentation.

\section{RESULTS}

The search strategy identified a total of 4,876 publications. After excluding 405 duplicates and 4,395 due to

Chart 1 - Search strategy according to the informational resource used in the review - Cuiabá-MT, Brazil, 2019-2020.

\begin{tabular}{|c|c|}
\hline $\begin{array}{l}\text { Information } \\
\text { resource }\end{array}$ & Search strategy \\
\hline $\begin{array}{l}\text { MEDLINE } \\
\text { (PubMed) }\end{array}$ & $\begin{array}{l}\text { ((leprosy[mesh terms]) or leprosy[tiab]) or leprosies[tiab]) or "hansen disease" [tiab]) or "hansen's disease" [tiab]) or "mycobacterium } \\
\text { leprae" [tiab]) or "mycobacterium infections" [tiab])) OR "Leprosy, Multibacillary"[Mesh] OR "Leprosy, Paucibacillary" [Mesh] } \\
\text { OR "Leprosy, Tuberculoid"[Mesh] OR "Leprosy, Lepromatous" [Mesh] OR "Leprosy, Borderline" [Mesh] and }((((()((((\text { quality of } \\
\text { life[mesh terms]) or "quality of life"[mesh major topic] or "qol" [tiab]) or "health related quality of life"[tiab]) or "health-related } \\
\text { quality of life" [tiab]) or "hrqol" [tiab]) or quality of life[tiab])) }\end{array}$ \\
\hline $\begin{array}{l}\text { COCHRANE } \\
\text { LIBRARY }\end{array}$ & $\begin{array}{l}\text { (lepr* or "hansen disease" or "hansens disease" or "hansen's disease" or "leprosies") and ("quality of life" or "health related quality } \\
\text { of life" or "health-related quality of life" ) limite: trials }\end{array}$ \\
\hline LILACS (BVS) & $\begin{array}{l}\text { ((hanseníase or leprosy or lepra or leprosies) and ("qualidade de vida" or "qualidade de vida relacionada à saúde" or "quality of } \\
\text { life" or "health related quality of life" or "health-related quality of life" or "calidad de vida" or "calidad de vida relacionada con } \\
\text { la salud") }\end{array}$ \\
\hline EMBASE & 'leprosy':ti,ab,kw and 'quality of life':ti,ab,kw \\
\hline CINAHL & $\begin{array}{l}\text { (mh "leprosy" or ti "leprosy" or ab "leprosy" or ti "hansen disease" or ab "hansen disease" or ab "hansens disease" or ab "hansen's } \\
\text { disease" or ti "leprosies" or ab "leprosies") and ( } \mathrm{mh} \text { "quality of life" or ti "quality of life" or ab "quality of life" or ti "health related } \\
\text { quality of life" or ab "health related quality of life" or ti "health-related quality of life" or ab "health-related quality of life" }\end{array}$ \\
\hline SCOPUS & $\begin{array}{l}\text { title-abs-key ("leprosy" or "hansen disease" or "hansens disease" or "hansen's disease" or "leprosies") and ("quality of life" or } \\
\text { "health related quality of life" or "health-related quality of life") }\end{array}$ \\
\hline $\begin{array}{l}\text { WEB OF } \\
\text { SCIENCE }\end{array}$ & $\begin{array}{l}\text { topic: (“"leprosy" or "hansen disease" or "hansens disease" or "hansen's disease" or "leprosies") and ("quality of life" or "health } \\
\text { related quality of life" or "health-related quality of life") }\end{array}$ \\
\hline PSYCINFO & $\begin{array}{l}\text { any field: (leprosy or "hansen disease" or "leprosies" or "hansens disease" or "hansen's disease") and any field: ("quality of life" or } \\
\text { "health related quality of life" or "health-related quality of life") }\end{array}$ \\
\hline INFOLEP & "quality of life" \\
\hline \multirow{3}{*}{$\begin{array}{l}\text { GOOGLE } \\
\text { SCHOLAR }\end{array}$} & strategy 1:"paucibacillary leprosy" "quality of life" \\
\hline & strategy 2: "lepromatous leprosy" "quality of life" \\
\hline & strategy 3: "quality of life" "leprosy patients" \\
\hline
\end{tabular}




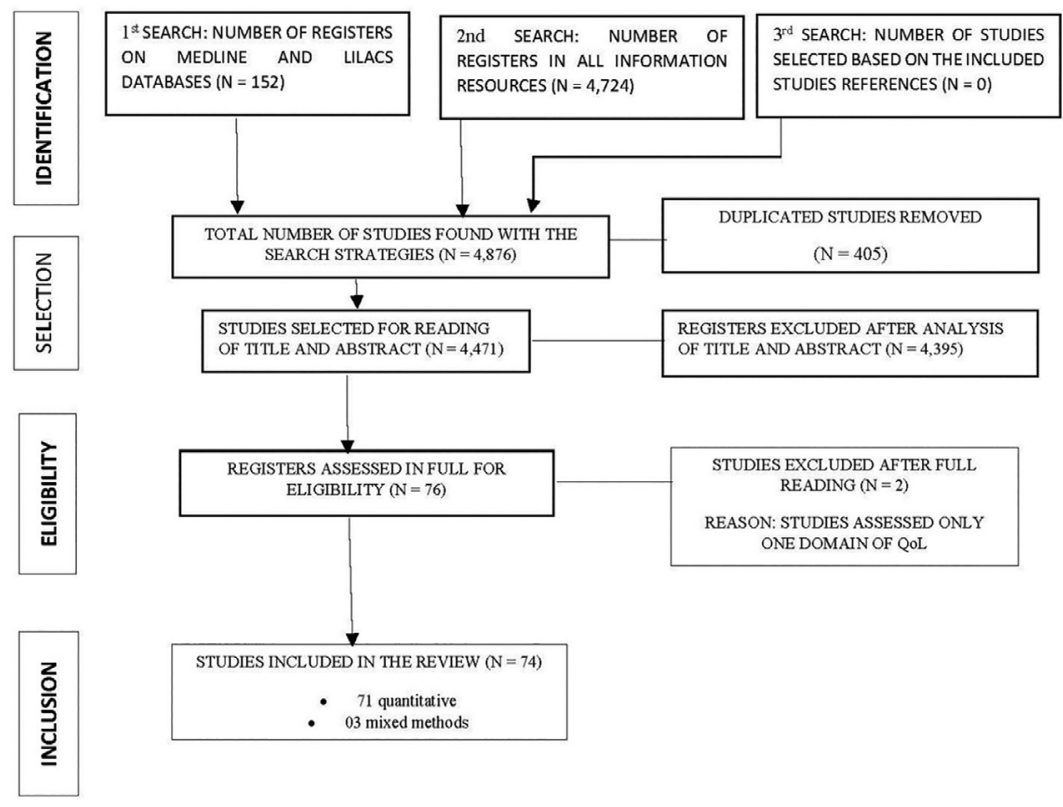

Figure 1 - Flow diagram of the selection of studies included in the review according to PRISMA ${ }^{(32)}$ - Cuiabá-MT, Brazil, $2019-2020$.

established eligibility criteria, 76 studies were selected for full reading. Of these, 2 were excluded for reporting only one QoL domain, resulting in a total of 74 studies included in the review. The description of the searches and the selection of articles were based on the Preferred Reporting Items for Systematic Review and Meta-Analysis (PRISMA) ${ }^{(32)}$ (Figure 1).

The 74 studies included in the scoping review were published mainly in English ( $\mathrm{n}=49 ; 66.2 \%)$, and carried out in 13 different countries, with Brazil presenting the highest number of publications $(n=43 ; 58.1 \%)$. The surveys were predominantly of the observational quantitative type $(n=64 ; 86.5 \%)$, and the mixed method (Questionnaire + Focus Group and Questionnaire + In-depth Interview) was the least cited in the studies included in the review $(n=3 ; 4.1 \%)$. Participants in the studies analyzed in the review were essentially older than 15 years $(n=72 ; 97.3 \%)$, mostly recruited from reference centers for leprosy treatment $(\mathrm{n}=39 ; 52.7 \%)$ (Table 1).

As for the year of publication, it was found that the first studies published in the databases on the subject date back to $1999^{(33)}$ and those with the highest records between the years $2015(n=12)$ and $2019(n=11)$.

There was a higher frequency of the validated instrument with general questions, the World Health Organization Quality Of Life-Bref-WHOQOL-BREF ( $\mathrm{n}=37 ; 50.0 \%$ ), and the Medical Outcome Study - Short form-36 - SF-36 $(\mathrm{n}=14 ; 18.9 \%)$, followed by the specific one for skin diseases Dermatology Life Quality Index - DLQI ( $=11 ; 14.9 \%)$. It was also found that $2.7 \%$ of the studies included in the review used both the general and the specific instrument to assess QoL (Table 2).

Regarding the results of the studies selected, the grouping of coincident themes allowed the construction of four categories that summarize the main findings and are
Table 1 - Characterization of scientific production on leprosy patients Quality of Life - Cuiabá-MT, Brazil, 2019-2020.

\begin{tabular}{|c|c|c|}
\hline Variables & $\mathbf{n}$ & $\%$ \\
\hline \multicolumn{3}{|l|}{ Studied population } \\
\hline$>15$ years & 72 & 97.3 \\
\hline$<15$ years & 2 & 2.7 \\
\hline \multicolumn{3}{|l|}{ Context } \\
\hline Reference centers for leprosy treatment & 39 & 52.7 \\
\hline Hospitals & 16 & 21.6 \\
\hline Community/primary health care & 12 & 16.2 \\
\hline Former isolation colonies & 7 & 9.5 \\
\hline \multicolumn{3}{|l|}{ Country } \\
\hline Brazil & 43 & 58.1 \\
\hline India & 14 & 18.9 \\
\hline Indonesia & 3 & 4.1 \\
\hline China & 2 & 2.7 \\
\hline Bangladesh & 2 & 2.7 \\
\hline Nigeria & 2 & 2.7 \\
\hline Others* & 8 & 10.8 \\
\hline \multicolumn{3}{|l|}{ Language } \\
\hline English & 49 & 66.2 \\
\hline Portuguese & 14 & 18.9 \\
\hline Portuguese/English & 11 & 14.9 \\
\hline \multicolumn{3}{|l|}{ Approach quantitative } \\
\hline Observational & 64 & 86.5 \\
\hline Experimental & 7 & 9.5 \\
\hline \multicolumn{3}{|l|}{ Mixed method } \\
\hline Questionnaire + Focus Group & 2 & 2.7 \\
\hline Questionnaire + In-Depth Interview & 1 & 1.4 \\
\hline
\end{tabular}


Table 2 - Distribution of studies included in the scoping review according to the instruments and domains used to assess leprosy patients Quality of Life - Cuiabá-MT, Brazil, 2019-2020.

\begin{tabular}{|c|c|c|c|}
\hline Instrument & Domains evaluated & $\mathbf{n}$ & $\%$ \\
\hline WHOQoL-Bref*(5-7,15-22,24-26,34-55) & Physical; Psychological; Social relationships; Environment & 37 & 50,0 \\
\hline SF-36*(2,10,56-67) & $\begin{array}{l}\text { Functional capacity; Physical aspects; Pain; General health status; Mental health; Emotional } \\
\text { aspects; Social aspects; Vitality }\end{array}$ & 14 & 18,9 \\
\hline DLQI**(8,68-77) & $\begin{array}{l}\text { Symptoms and feelings; Daily activities; Leisure activities and sports practices; Work and } \\
\text { school; Interpersonal relationships; Treatment }\end{array}$ & 11 & 14,9 \\
\hline WHOQoL-100*(33,47) & $\begin{array}{l}\text { Physical; Psychological; Level of independence; Social relationships; Environment; } \\
\text { Spirituality/Personal Beliefs }\end{array}$ & 2 & 2,7 \\
\hline DLQI** and SF-36 $6^{*(78-79)}$ & $\begin{array}{l}\text { Functional capacity; Physical aspects; Pain; General health status; Mental health; Emotional } \\
\text { aspects; Social aspects; Vitality }\end{array}$ & 2 & 2,7 \\
\hline PedsQL $4.0^{*(80)}$ & Physical; Emotional; Social; Educational & 1 & 1,4 \\
\hline NeuroQol**(81) & $\begin{array}{l}\text { Pain, Loss/Reduced sensitivity, Diffuse sensory-motor symptoms, Limitations of activities in } \\
\text { daily life, Disorder in social relationships and distress } \\
\text { Emotional }\end{array}$ & 1 & 1,4 \\
\hline CDLQI**(82) & $\begin{array}{l}\text { Symptoms and feelings; Leisure; School or vacation; Personal relationships; Sleep and } \\
\text { treatment }\end{array}$ & 1 & 1,4 \\
\hline W-QLI*(83) & $\begin{array}{l}\text { Level of satisfaction; Psychological well-being; Mental symptoms; Physical health; Finances; } \\
\text { Activities of daily living }\end{array}$ & 1 & 1,4 \\
\hline RAND-36*(84) & $\begin{array}{l}\text { Functional capacity; Physical aspects; Pain; General health status; Mental health; Emotional } \\
\text { aspects; Social aspects; Vitality }\end{array}$ & 1 & 1,4 \\
\hline SF-20*(85) & $\begin{array}{l}\text { Physical ability; Limitation due to illness; Mental health; Health perception; Social aspects; } \\
\text { Pain }\end{array}$ & 1 & 1,4 \\
\hline Standardized instrument ${ }^{(86) * * *}$ & Does not specify & 1 & 1,4 \\
\hline Not mentioned ${ }^{(87) * * * *}$ & - & 1 & 1,4 \\
\hline \multicolumn{2}{|l|}{ Total } & 74 & 100 \\
\hline \multicolumn{4}{|c|}{$\begin{array}{l}\text { *general validated instrument: World Health Organization Quality of Life-Bref (WHOQOL-bref); Medical Outcome Study - Short form-36 (SF-36); World Health } \\
\text { Organization Quality of Life-100 (WHOQoL-100); Pediatric Quality of Life InventoryTM version 4.0 (PedsQL 4.0); Short Form Health Survey (RAND-36); Shor } \\
\text { Form-20 (SF-20); Wisconsin-Quality of Life Index (W-QLI). } \\
\text { **ssecific validated instrument: Dermatology Life Quality Index (DLQI); Quality of Life in Neurological Disorders (Neuro-QoL); Children's Dermatology Life } \\
\text { Quality Index (CDLQI). } \\
* * * \text { Instrument not validated. } \\
\text { **** no information. }\end{array}$} \\
\hline
\end{tabular}

presented in Chart 2:1) Interventions and the impact on leprosy patients QoL; 2) Comparison of leprosy patients QoL and that of other populations; 3) Leprosy patients QoL characterization, and 4) Impact of leprosy on the QoL of children and adolescents with leprosy,

In category 1 , only seven of the reviewed studies used the assessment of $\mathrm{QoL}$ as an outcome investigated following interventions. These studies included surgical ${ }^{\left({ }^{(4)}\right.}$ interventions, as well as those of self-care oriented health education $^{(58)}$, therapeutic workshops ${ }^{(43)}$, stretching-specific physical therapy ${ }^{(56)}$, medication with emphasis on the treatment of type 1 leprosy reaction ${ }^{(60)}$, and neuropathic pain $^{(51)}$.

In category 2 , on the comparison of the QoL of patients with leprosy with other populations, the studies showed worse QoL scores when compared to patients with other dermatoses and the general population.

Findings presented in category 3 indicated that QoL was frequently related to disease progression (time of treatment, multibacillary forms, leprosy reactions, disabilities, deformities, stigma, and neuropathic pain), and the physical domain had the worst scores in the assessment.

The findings in category 4 indicated that among the 74 studies included in the review, only two $(2.7 \%)$ investigated the child-juvenile population regarding the assessment of quality of life related to leprosy. Such evidence indicates moderate impairment of QoL in this age group ${ }^{(82)}$ and also lower HRQoL scores when children presented musculoskeletal manifestations, mainly in the domains of physical capacity and school activities ${ }^{(80)}$.

\section{DISCUSSION}

Quality of life has established itself as a significant concept in the health area, both in research and in care practice. In the present review, it was identified that, in recent years, a significant number of studies have focused on investigating leprosy patients QoL. As a result, it brought a better understanding of the disease, of treatment and, consequently, of decision-making at different levels of care ${ }^{(88)}$.

The review showed Brazil as the country with the largest number of published studies from reference centers for leprosy treatment. These findings confirm the hyperendemicity of the disease in the country ${ }^{(1)}$, related to factors regarding social, demographic, and economic aspects, among others. These factors can interfere with the population's access to health services, resulting in late diagnosis and, consequently, in physical disability, observed in advanced clinical forms of the disease, which would justify the fact that 
Chart 2 - Synthesis of evidence on the assessment of the leprosy patients Quality of Life - Cuiabá-MT, Brazil, $2019-2020$.

\begin{tabular}{|c|c|}
\hline Category & Main findings \\
\hline \multirow{7}{*}{ (1) } & $\begin{array}{l}\text { There was no significant difference in quality of life between the group treated for leprosy-related neuritis on an outpatient basis and } \\
\text { those that were hospitalized }{ }^{(47)} \text {. }\end{array}$ \\
\hline & $\begin{array}{l}\text { The performance of surgical intervention for nerve decompression in patients with leprosy-related neuropathy resulted in a significant } \\
\text { improvement in } \mathrm{QoL}^{(84)} \text {. }\end{array}$ \\
\hline & $\begin{array}{l}\text { The use of a manual containing guidelines on self-care for the prevention of disability showed a statistically significant improvement } \\
\text { in the domains of pain and social aspects of } \mathrm{QoL}^{(58)} \text {. }\end{array}$ \\
\hline & $\begin{array}{l}\text { The performance of therapeutic workshops (arts, music and recreation/games) showed a statistically significant improvement in the } \\
\text { physical, psychological, and environment domains of } \operatorname{QoL}^{(43)} \text {. }\end{array}$ \\
\hline & The application of passive static stretching exercises in the treatment of leprosy sequelae provided significant gains in quality of life ${ }^{(56)}$. \\
\hline & $\begin{array}{l}\text { Those with type I leprosy reaction treated with cyclosporine }{ }^{\circledR} \text { and prednisolone }{ }^{\circledR} \text {, as well as those treated only with prednisolone, } \\
\text { showed a significant improvement in quality of life, although without significant difference between the two groups }{ }^{(60)} \text {. }\end{array}$ \\
\hline & Botulinum toxin type A proved to be a good therapeutic option for pain relief with improved quality of life for leprosy patients ${ }^{(51)}$. \\
\hline \multirow{2}{*}{$(2)$} & Leprosy patients had worse QoL scores when compared to those with other dermatoses ${ }^{(35,71)}$. \\
\hline & Leprosy patients indicated worse QoL scores when compared to the general population ${ }^{(15,22,24,33,37,40,66)}$. \\
\hline \multirow{17}{*}{ (3) } & Paucibacillary leprosy showed better QoL scores ${ }^{(2,8,74,76,78-79)}$. \\
\hline & Leprosy patients residing in the Brazilian Southeast region indicated better QoL scores ${ }^{(70)}$. \\
\hline & Better QoL scores were observed among leprosy patients who completed the treatment ${ }^{(34)}$. \\
\hline & Leprosy compromises mainly the physical component of QoL ${ }^{(2,6-7,10,15-20,22-23,34,44,48-49,52,56-58,60-61,63-65,84)}$. \\
\hline & There is QoL impairment in leprosy reactions patients ${ }^{(8,16,66,76)}$, with greater effect in patients with Erythema Nodosum Leprosum ${ }^{(2,61-62,66,73)}$. \\
\hline & Patients with isolated neuritis had significantly lower mean in all QoL domains compared to individuals without reaction ${ }^{(66)}$. \\
\hline & The presence of pain has a negative impact on the assessment of the QoL of leprosy patients ${ }^{(15,17,42,49,52,63)}$. \\
\hline & $\begin{array}{l}\text { Disability due to leprosy is related to greater impairment of quality of life }{ }^{(2,4,26,35,48,57,76)} \text {, being higher among those with visible } \\
\text { disability }(34-36,38-39,54,56,77) \text {. }\end{array}$ \\
\hline & Stigma has a negative impact on the leprosy people QoL ${ }^{(7,36,38,52)}$. \\
\hline & The combination of neuropathy and stigma significantly increases QoL impairment ${ }^{(52)}$. \\
\hline & Leprosy patients with altered psychological health had low QoL scores ${ }^{(24-26)}$. \\
\hline & $\begin{array}{l}\text { The greater the limitation of activity in individuals affected by leprosy, the lower the QoL, mainly affecting the physical and } \\
\text { environmental domains }{ }^{(6,48)} \text {. }\end{array}$ \\
\hline & There was no significant association between physical activities and quality of life in individuals with leprosy ${ }^{(54)}$. \\
\hline & $\begin{array}{l}\text { There was a significant difference in the domain of social, physical and psychological relationships among leprosy patients with } \\
\text { symptoms of testicular dysfunction and patients without these symptoms }{ }^{(53)} \text {. }\end{array}$ \\
\hline & $\begin{array}{l}\text { There was a relationship between family support and quality of life in leprosy patients, and the greater the family support, the better } \\
\text { the quality of life }{ }^{(55)} \text {. }\end{array}$ \\
\hline & The longer the duration of the disease, the greater the impact on $\mathrm{QoL}^{(26,39,77)}$. \\
\hline & Leprosy negatively impacts QoL even after treatment is completed ${ }^{(69-77)}$. \\
\hline \multirow[b]{2}{*}{ (4) } & There is moderate impairment of the quality of life in leprosy patients under 15 years of age ${ }^{(82)}$. \\
\hline & $\begin{array}{l}\text { Children and adolescents with leprosy and musculoskeletal manifestations had lower HRQoL scores in the domains of physical } \\
\text { capacity and school activities when compared to those without these manifestations }{ }^{(80)} \text {. }\end{array}$ \\
\hline
\end{tabular}

the population, in most studies, was recruited from reference units for the disease ${ }^{(89)}$.

Leprosy remains a disease of difficult control for public health in endemic countries ${ }^{(1)}$. Recently, the Ministry of Health of Brazil launched the National Strategy for Coping with the disease and, for the first time, patients' subjectivity and the specificity of each region of the country were respected, with different strategies being presented for each of them, according to geographic characteristics ${ }^{(89)}$. In this context, the need to consider the subjectivity of each individual and the lifestyle in the society in which they live to reduce the impact of the disease on their $\mathrm{QoL}^{(90-92)}$ is highlighted.
The studies included in the current review were predominantly cross-sectional studies of quantitative approach. It should be noted that quantitative data on $\mathrm{QoL}$ assessment, despite reflecting the multidisciplinary nature of the human focus on their domains, may not capture their subjectivity, so the inclusion of qualitative approaches is essential. Qualitative studies allow capturing valuable information about the experiences and needs of patients in specific contexts, in addition to facilitating the understanding and interpretation of the meaning of quality of life, as well as the aspects that most affect it ${ }^{(12,93-94)}$.

As for the population characteristics, the surveys essentially included adults and/or the elderly, during or after 
treatment. None of the retrieved studies specifically investigated patients being retreated, with treatment resistance, or even assessed the individuals' QoL over time. Thus, the current review failed to adequately address QoL among some groups whose experience may substantially differ from that of other leprosy patients.

Furthermore, only $2.7 \%$ of the total number of studies included in the review assessed the leprosy children and adolescents QoL. It is believed that the knowledge gap identified in this age group may be related to the lower prevalence of leprosy in this group than in adults, making it difficult to gather findings, as well as to the challenges of assessing children and adolescents QoL, such as the need for specific tools to measure it, interpretation of evaluated $\mathrm{QoL}$ measures, as a proxy, including children and their guardians, as well as ethical issues involving the participation of this population in research ${ }^{(82,95)}$. The increase in the number of cases of this disease in children and adolescents is an important epidemiological indicator and is intrinsically linked to the deficit in detecting the disease, which significantly increases its transmission rates ${ }^{(96)}$.

Studies on leprosy in children and adolescents in Brazil demonstrate the need for better orientation of public health policies for its continuous and systematic surveillance, which also includes intra-household and social contacts, contributing to the understanding of the endemic behavior of the disease. Leprosy in this population, when diagnosed late, can lead to psychological sequelae that are difficult to treat and directly impact their quality of life and family ${ }^{(80,82,97-99)}$.

Studies have shown that QoL assessment is complex, and requires multiple measures to capture its subjectivity and multidimensionality, so that several instruments were developed to measure it ${ }^{(91)}$. As highlighted above, instruments with general questions provide a broader assessment and can be used for comparisons among different types of diseases and their degree of severity and treatments, as well as different demographic groups. The specific ones, on the other hand, propose to measure particular aspects of certain conditions in QoL, which may be exclusive to a special disease, condition, function or population ${ }^{(10,13,14,91)}$.

Regarding the instruments used to assess leprosy patients QoL, the review identified three validated instruments that were most frequently applied, the WHOQolbref (50\%), the SF-36 (18.9\%), and the DLQI (14.9\%). The WHOQol-bref is a general instrument - short version of the WHOQOL-100, consisting of 26 items divided into 4 domains (physical, psychological, social relations, and environment) ${ }^{(14,100)}$. The SF-36, an instrument that also includes general health-related aspects, is intended to detect relevant clinical and social differences in health status, both in the general population and in individuals affected by any disease, as well as changes in health over time. The SF-36 questions are divided into two major components: the physical one, which includes the functional capacity, general health, pain, and physical aspects domains; and the mental one, which covers mental health, vitality, social, and emotional aspects ${ }^{(11)}$. The specific QoL questionnaire for skin diseases, DLQI, consists of ten items that are divided into six domains: 1 - Symptoms and feelings; 2 - Daily activities; 3 - Leisure; 4 - Work/school; 5 - Interpersonal relationships; and 6 - Treatment ${ }^{(101)}$.

The literature indicates that instruments addressing general QoL issues, such as the WHOQolbref and the SF-36, despite allowing the assessment of different areas or domains of different populations with different diseases, have the disadvantage of not incorporating all factors relevant to the QoL of groups with specific diseases ${ }^{(93)}$; it is possible that some aspects inherent to leprosy have been under-evaluated by this type of instrument ${ }^{(47,65-66)}$.

Specific questionnaires for a particular group of diseases, such as the DLQI, focus on common aspects of different diseases, allowing comparisons among related but distinct populations, being particularly important for infrequent diseases, as they help to overcome the limitations associated with small samples ${ }^{(88,101)}$.

It should be noted that the association of a general and specific instrument ${ }^{(95)}$ is recommended, as this ensures a more comprehensive view when evaluating different aspects of QoL, producing both general data, which facilitate comparisons between different health problems, and related data, specifically, the impact of a given disease on QoL. However, this association is uncommon in studies on leprosy people QoL, and was observed in only $2.7 \%$ of the studies included in this review ${ }^{(78-79)}$.

The findings of this study showed that physical domain which mainly covers the assessment of pain and discomfort, dependence on medication or treatment, energy and fatigue, sleep and rest, mobility, daily activities and work capacity often had lower scores in the QoL assessment in studies with leprosy patients ${ }^{(10,15-23,44,56-61,63-65)}$. However, it is highlighted that the change in people's lives, based on the symptoms and signs of the disease, the reactions and the development of disabilities, can lead to social isolation, work losses, difficulty in accepting the disease process and self-care; therefore, reaching not only the physical component, but also the emotional, social, and environmental component, as demonstrated in some studies ${ }^{(7,24,34-43,45,72)}$.

The studies included in this review showed that leprosy individuals had significantly lower QoL when compared to populations with other dermatoses ${ }^{(35,71)}$ and the general population ${ }^{(15,22,24,33,37,40,66)}$, which is corroborated by other studies that indicate that factors such as delayed diagnosis ${ }^{(2,8,43,74,76,78-79)}$, the presence of leprosy reactions $^{(2,8,16,61-62,72)}$, disability ${ }^{(5,8,39,72)}$, neuropathic pain ${ }^{(7,17-18,63,86)}$, and stigma ${ }^{(2,41,54)}$ are often associated with greater losses in QoL.

Other studies, in their turn, show that early diagnosis and treatment ${ }^{(2,5,25,39,47,70,76-77)}$, the multidisciplinary approach to the patient ${ }^{(10,12,15,33,41,59,65,73,81-82,86)}$, the fight against social stigma ${ }^{(15,25,40,63,82,86)}$, the development of actions aimed at the prevention and appropriate management of disabilities ${ }^{(5-6,8,28,64,71,85)}$, health education for patients affected by leprosy ${ }^{(39,54,77)}$, and adequate follow-up in the post-discharge period $^{(22,38,70)}$ are critical to improve the $\mathrm{QoL}$ of these individuals. 
The study has its limitations because the evidence from observational research identified in the review shall be interpreted taking into account the possible biases inherent to the methodological design, which in itself weakens the analysis of results. In addition, other aspects such as variation in the instruments used, and the different ways of reporting QoL results, made comparison difficult. Another issue is the population selected in the surveys, mostly from reference centers for the treatment of leprosy, that is, patients in an advanced stage of the disease and often with physical disabilities already installed, which may have indicated the greater negative impact on the physical aspects of QoL.

\section{CONCLUSION}

The assessment of QoL was more frequently developed in hyperendemic countries, in adults, with late disease progression, and mostly through instruments that assessed general QoL issues. Evidence indicated impairment of the physical domain related to delayed diagnosis, leprosy reactions, physical disabilities, neuropathic pain, and stigma as the main aspects linked to the worst scores in the assessment of QoL. However, the review identified that the improvement in the QoL of patients was related to early diagnosis and treatment, health education, a multidisciplinary approach, prevention of physical disabilities and stigma.

One can point out as knowledge gaps, evidenced in this review, the lack of research with children and adolescents, studies that used general and specific instruments together for the assessment of QoL, as well as those with a qualitative approach.

Greater investments in future research with the children and young population are recommended to investigate the perception that this group has of their health status, using parameters and instruments appropriate to this age group, as well as studies that demonstrate the effectiveness of evaluative interventions, as well as the proposition of validated instruments that include information from both general and specific domains and directed to each population. The development of studies with a qualitative approach or a mixed method are also suggested.

It is thought that the insertion of a Care Model for Leprosy Care in care practice could ensure more qualified care directed to the prevention, rehabilitation of physical disabilities, and management of stigma. In this regard, the need to include systematized care protocols that are applied in a multidisciplinary way, at all levels of care, supported by scientific evidence, is also highlighted.

\section{RESUMO}

Objetivo: Explorar as evidências científicas relativas à qualidade de vida de pacientes com hanseníase. Método: revisão de escopo segundo a metodologia do Instituto Joanna Briggs, com artigos indexados nas bases de dados PubMed, Cochrane, LILACS, Embase, CINAHL, Scopus, Web of Science, PsyINFO, INFOLEP e Google Scholar, publicados na íntegra em português, inglês ou espanhol. Resultados: identificaram-se 74 estudos, sendo 71 de abordagem quantitativa e 3 com método misto. Houve predominância de estudos publicados no Brasil $(58,1 \%)$, com população adulta $(97,3 \%)$ e recrutada em centros de referência para tratamento de hanseníase (52,7\%). Verificou-se maior utilização dos instrumentos WHOQOL-bref (50\%) e SF-36 (18,9\%) para avaliação da qualidade de vida. $\mathrm{O}$ estudo evidenciou que o maior comprometimento da qualidade de vida se relacionou ao atraso no diagnóstico da doença, às reações hansênicas, às incapacidades físicas, à dor neuropática e ao estigma. Conclusão: as pesquisas foram desenvolvidas em sua maioria em países endêmicos, com adultos e a partir de estudos observacionais, sendo que os piores escores obtidos se associaram ao comprometimento do domínio físico.

\section{DESCRITORES}

Hanseníase; Qualidade de Vida; Doenças Negligenciadas; Revisão.

\section{RESUMEN}

Objetivo: Explotar las evidencias científicas con relación a la calidad de vida de pacientes con lepra. Método: revisión de alcance según la metodología del Instituto Joanna Briggs, con artículos indexados en las bases de datos PubMed, Cochrane, LILACS, Embase, CINAHL, Scopus, Web of Science, PsyINFO, INFOLEP y Google Scholar, publicados integralmente en portugués, inglés o español. Resultados: se identificaron 74 estudios, entre los cuales 71 fueron de abordaje cualitativo y 3 con método mixto. Predominaron estudios publicados en Brasil (58,1\%), con población adulta $(97,3 \%)$ y convocada en centros de referencia para tratamiento de lepra (52,7\%). Se verificó mayor utilización de los instrumentos WHOQOL-bref (50\%) y SF-36 (18,9\%) para evaluación de la calidad de vida. El estudio mostró que los factores que más afectaron la calidad de vida fueron el retraso en el diagnóstico de la enfermedad, las reacciones leprosas, las discapacidades físicas, el dolor neuropatico y el estigma. Consideraciones Finales: las investigaciones fueron desarrolladas en gran parte en países endémicos, con adultos y a partir de estudios de observación, por lo que los peores resultados obtenidos se asociaron a las complicaciones del dominio físico.

\section{DESCRIPTORES}

Lepra; Calidad de Vida; Enfermedades Desatendidas; Revisión.

\section{REFERENCES}

1. WHO. Global leprosy update, 2019: time to step-up prevention initiatives. Wkly Epidemiol Rec 2020;36(95):417-440.

2. Lustosa AA, Nogueira LT, Pedrosa JIS, Teles JBM, Campelo V. The impact of leprosy on health-related quality of life. Rev Soc Bras Med Trop [Internet]. 2011 [cited 2021 Mar 12];44(5):621-6. Available from: http://www.scielo.br/scielo.php?script=sci_arttext\&pid=S0037$86822011000500019 \& \operatorname{lng}=e n$.

3. Monte RS, Pereira MLD. Hanseníase: representações sociais de pessoas acometidas. Rev Rene. 2015;16(6):863-71. 
4. Santos K da S, Fortuna CM, Santana FR, Gonçalves MFC, Marciano FM, Matumoto S. Significado da hanseníase para pessoas que viveram o tratamento no período sulfônico e da poliquimioterapia. Rev Lat Am Enfermagem. 2015;23(4):620-627.

5. Gaudenci EM, Nardelli GG, Almeida Neto OP, Malaquias BSS, Carvalho BT, Pedrosa LAK. Qualidade de Vida, Sintomas Depressivos e Incapacidade Física de Pacientes com Hanseníase. Hansen Int 2015;40(2):48-58.

6. Terra FS, Costa RD, Lyon S, Costa AMDD, Figueiredo Antunes CM. Assessment of quality of life of patients with leprosy reactional states treated in a dermatology reference center. An Bras Dermatol. 2012;87(1):26-35.

7. Santos VS, Oliveira LS, Castro FD, Gois-Santos VT, Lemos LM, Ribeiro Mdo C, et al. Functional Activity Limitation and Quality of Life of Leprosy Cases in an Endemic Area in Northeastern Brazil. PLoS Negl Trop Dis. 2015;9(7):e0003900.

8. Martins BDL, Torres FN, Oliveira MLWDR. Impacto na qualidade de vida em pacientes com hanseníase: correlação do Dermatology Life Quality Index com diversas variáveis relacionadas à doença. An Bras Dermatol. 2008;83(1):39-43.

9. WHOQOL G. The World Health Organization Quality of Life Assessment (WHOQOL): position paper from the World Health Organization. Social Science \& Medicine. 1995;41(10):1403-9.

10. Araújo DAL, Brito KKG, Santana EMF, Soares VL, Soares MJGO. Caracterização da qualidade de vida de pessoas com hanseníase em tratamento ambulatorial. Rev Pesqui Cuid. Fundam. 2016;8(4):5010-6.

11. Ciconelli RM, Ferraz MB, Santos W, Meinão I, Quaresma MR. Tradução para a língua portuguesa e validação do questionário genérico de avaliação de qualidade de vida SF-36 (Brasil SF-36). Ver Bras Reumatol. 1999;39:(3)143-50.

12. Seidl EMF, Zannon CMLC. Qualidade de vida e saúde: aspectos conceituais e metodológicos. Cad Saúde Pública [Internet]. 2004 [cited 2021 Mar 12];20(2):580-8. Available from: http://www.scielo.br/scielo.php?script=sci_arttext\&pid=S0102-311X2004000200027\&Ing = en.

13. Scattolin F. Qualidade de vida: a evolução do conceito e os instrumentos de medida. Revista da Faculdade de Ciências Médicas de Sorocaba. 2007;8(4):1-5.

14. The World Health Organization Quality of Life Assessment (WHOQOL): Development and general psychometric properties. Soc Sci Med. 1998;46(12):1569-85.

15. Tsutsumi A, Izutsu T, Islam AM, Maksuda AN, Kato H, Wakai S. The quality of life, mental health, and perceived stigma of leprosy patients in Bangladesh. Soc Sci Med. 2007;64(12):2443-53.

16. Loose JTT, Diniz SN, Cunha DF, Batista EC, Carlotto MS, Ferreira DF. Qualidade de vida em mulheres com episódios reacionais hansênicos em uso de prednisona no município de Rolim de Moura-RO. Rev Ciênc Saúde. 2017;2(2):1-10.

17. Reis FJJ dos, Gomes MK, Cunha AJLA da. Avaliação da limitação das atividades diárias e qualidade de vida de pacientes com hanseníase submetidos à cirurgia de neurólise para tratamento das neurites. Fisioterapia e Pesquisa. 2013;20(2):184-90.

18. Reis FJJ, Gomes MK, Rodrigues J, Gosling AP, Fontana AP, Cunha AJLA. Pain and Its Consequences in Quality of Life: A Study with WHOQOL-Bref in Leprosy Patients with Neuropathic Pain. ISRN Trop Med. 2013;2013:e987683.

19. Reis FJJ, Lopes D, Rodrigues J, Gosling AP, Gomes MK. Psychological distress and quality of life in leprosy patients with neuropathic pain. Lepr Rev. 2014;85(3):186-93

20. Reis FJ, Cunha AJ, Gosling AP, Fontana AP, Gomes MK. Quality of Life and its domains in leprosy patients after neurolysis: A study using WHOQOL-BREF. Lepr Rev. 2013;84(2):119-23.

21. Santos VS, Santana JC, Castro FD, Oliveira LS, Santana JC, Feitosa VL, et al. Pain and quality of life in leprosy patients in an endemic area of Northeast Brazil: a cross-sectional study. Infect Dis Poverty. 2016;5:18.

22. Savassi LCM, Bogutchi TR, Pinheiro A, Oliveira S, Modena CM. A influência da internação compulsória em Hospitais- colônia na qualidade de vida de cuidadores e pacientes com sequelas de hanseníase. Hansen Int. 2009;34(2):21-31.

23. Savassi LCM, Bogutchi TRS, Lima ACL, Modena CM. Quality of life of leprosy sequelae patients living in a former leprosarium under home care: univariate analysis. Qual Life Res. 2014;23(4):1345-51.

24. José A, Soares CLR, Marchiori M, Lanza FC, Dal Corso S, Malaguti C. The glittre-ADL test can be used to assess the functional performance in patients with leprosy: A controlled transversal study. Edorium J Disabil Rehabil. 2016;20(3):223-30.

25. Xiong M, Wang X, Su T, Yang B, Li M, Zheng D. Relationship between psychological health and quality of life of people affected by leprosy in the community in Guangdong province, China: a cross-sectional study. BMC Public Health. 2019;19(1):424.

26. Barakat M, Zaki H. Relationship between Psychological Problems and Quality of Life among Leprosy Patients. Evidence-Based Nursing Research. 2019;1(2):15.

27. Theofilou P. Quality of Life: definition and measurement. Europ J Psychol. 2013;9(1):150-62

28. Silva MBA, Santos ICF, Araújo KBS, Brito MIBS. Aspectos psicossociais nos portadores de Hanseníase em um centro de referência de Pernambuco. Rev Enferm Digit Cuid Promoção Saúde. 2018:3(2):54-9.

29. Aromataris E, Munn Z, editors. JBI Manual for Evidence Synthesis. JBI. 2020. DOI: http://dx.doi.org/10.46658/JBIMES-20-01.

30. Post M. Definitions of quality of life: What has happened and how to move on. Top Spinal Cord Inj Rehabil. 2014;20(3):167-80.

31. Nicolussi A, Sawada N. Factors that influence the quality of life of patients with colon and rectal cancer. Acta Paulista de Enfermagem. 2010;23(1):125-30.

32. Moher D, Liberati A, Tetzlaff J, Altman DG, PRISMA Group. Preferred reporting items for systematic review and meta-analysis protocols (PRISMA-P) 2015 statement. PLoS Med. 2009;6(7):e1000097.

33. Joseph GA, Rao PSSS. Impact of leprosy on the quality of life. Bulletin of the World Health Organization. 1999;77(6):515-7.

34. Umoh KA, Effiong JH. Quality of life of persons newly diagnosed with leprosy in Akwa Ibom state. Int J Health Sci Res. 2015;5(6):512-7. 
35. Albinism. International Neuropsychiatric Disease Journal. 2016;6(4):1-6.

36. Manna N, Chakraborty A, Sarkar S, Sarkar M, Pradhan U. Higher educational status, staying in joint family and early treatment initiation improves Quality of Life in leprosy: experiences from and observational study at a tertiary centre in Eastern Índia. Global Journal of Medicine and Public Health. 2015;4(2):1-7.

37. Mankar MJ, Joshi SM, Velankar DH, Mhatre RK, Nalgundwar AN. A comparative study of the quality of life, knowledge, attitude and belief about leprosy disease among leprosy patients and community members in Shantivan Leprosy Rehabilitation centre, Nere, Maharashtra, India. J Global Infect Dis. 2011;3(4):378-82.

38. Kumar DG, John KR, Logaraj M. An assessment of quality of life among leprosy affected persons residing in leprosy settlements of Chengalpet Taluk, Kancheepuram, Tamil Nadu. Natl J Res Community Med. 2016;5(3):149-54.

39. Govindharaj P, Srinivasan S, Darlong J. Quality of Life of People Affected with Leprosy Disability Living in Purulia. West Bengal Int J Health Sci Res. 2018;8(2):221-5.

40. Brouwers C, van Brakel WH, Cornielje H, Pokhrel P, Dhakal KP, Banstola N. Quality of Life, perceived stigma, activity and participation of people with leprosyrelated disabilities in South-East Nepal. Disability, CBR and Inclusive Development. 2011;22(1):16-34.

41. Chingu D, Duncan M, Amosun S. The quality of life of people with leprosy-related residual impairment and disability in Malawi - Is there a difference between people living in a leprosarium and those re-integrated into their communities? Lepr Ver. 2013;84(4):292-301.

42. Simões S, Castro S, Scatena L, Castro R, Lau F. Qualidade de vida dos portadores de hanseníase num município de médio porte. Medicina (Ribeirao Preto Online). 2016;49(1):60-7.

43. Leite SCC, Caldeira AP. Oficinas terapêuticas para a reabilitação psíquica de pacientes institucionalizados em decorrência da hanseníase. Ciênc saúde coletiva. 2015;20(6):1835-42.

44. Quaggio CMP, Virmond MCL, Guimarães HCQCP. Qualidade de vida da pessoa tratada da hanseníase. Hansen Int. 2014;39(2):36-46.

45. Leite IF, Arruda AJCG, Vasconcelos DIB, Santana SC, Chianca KSV. The quality of life of patients with chronic leprosy. Journal of Nursing UFPE on line. 2015;9(6):8165-71.

46. Geetha K, Dhanalakshmi A, Judie A. A study to assess the impact of leprosy on quality of life among leprosy patients in government rehabilitation home at Paranur. International Journal of Pharmaceutical and Clinical Research. 2015;7(6):466-8.

47. Ravi HN, George R, Eapen EP, Pulimood SA, Gnanamuthu C, Jacob M, et al. A Comparison of Economic Aspects of Hospitalization Versus Ambulatory Care in the Management of Neuritis Occurring in Lepra Reaction. International Journal of Leprosy and Other Mycobacterial Diseases. 2004;72(4):448-56.

48. Maranhão-Ferreira-Silva P, Esteves-Pereira L, Lima-Ribeiro L, Moura-dos-Santos D, Delmondes-do-Nascimento R, Steremberg-PiresD'Azevedo S. Evaluation of the physical limitations, psychosocial aspects and quality of life of people affected by leprosy. Revista de Pesquisa: Cuidado é Fundamental Online. 2019;11(1):211-5.

49. Lima SM, Brito KKG, Santana EMF, Nóbrega MM, Carvalho PS, Oliveira SHS, et al. Qualidade de vida de pacientes com reações hansênicas. Cogitare enferm. 2019;24:e62921. DOI: http://dx.doi.org/10.5380/ce.v24i0.62921.

50. Govindharaj P, Srinivasan S, Darlong J. Quality of Life of Persons Affected by Leprosy in an Endemic District, West Bengal, India. Indian J Dermatol. 2018;63(6):459-64.

51. Sousa EJS, Sousa GC, Baia VF, Somensi DN, Xavier MB. Botulinum toxin type A in chronic neuropathic pain in refractory leprosy. Arq Neuro-Psiquiatr. 2019;77(5):346-51

52. D’Azevedo SSP, Santos DCM, Alves MGT, Sousa NMN, Arruda GA, Lima MCV. Qualidade de vida de pessoas afetadas pela hanseníase inseridas em grupos de apoio ao autocuidado. Cogitare Enfermagem. 2019;(24):e64266.

53. Mohta A, Agrawal A, Sharma P, Singh A, Garg S, Kushwaha RK, et al. Endocrinological testicular dysfunction in patients with lepromatous leprosy and the impact of disease on patient's quality of life. Indian Dermatol Online J. 2020;11(6):959-64.

54. Utama APW, Hastuti P, Rustam MZA. The Relationship of Degree of Disability and Quality of Life Among Released From Treatment People Affected by Leprosy in Surabaya, Indonesia. Indian J Lepr. 2020;(92):97-107.

55. Mahanani S, Whant TK. Family Support Improving Quality Of Life Leprosy Patients. Pelita Health and Education Journal. 2020;1 (2):34-7.

56. Diaz AF, Moro FL, Binotto JM, Fréz AR. Estudo comparativo preliminar entre os alongamentos proprioceptivo e estático passivo em pacientes com sequelas de hanseníase. Fisioterapia e Pesquisa. 2008;15(4):339-44.

57. Amorim AAS, Pereira ISSD, Silva Júnior EG. Análise da qualidade de vida de pacientes acometidos por hanseníase. Journal of Infection Control. 2016;5(4):1-12.

58. Gonçalves M, Barros ARSB, Mazzer N, Elui VMC, Fonseca MCRF. Prevenção de incapacidade na hanseníase com apoio em um manual de autocuidado para pacientes. Fisioterapia e Pesquisa. 2010;17(2):157-66.

59. Lopes Neto D, Araújo RO, Meneghini MEF, Tsuzuki LM. Avaliação da qualidade de vida em pacientes com hanseníase: uso do Medical Outcomes Study 36. Rev Bras Pesq Saúde. 2015;17(1):6-10.

60. Lambert SM, Alembo DT, Nigusse SD, Yamuah LK, Walker SL, Lockwood DN. A randomized controlled double blind trial of ciclosporin versus prednisolone in the management of leprosy patients with new type 1 reaction, in Ethiopia. PLoS Negl Trop Dis. 2016;10(4):1-29.

61. Sales AM, Illarramendi X, Walker SL, Lockwood D, Sarno EN, Nery JAC. The impact of erythema nodosum leprosum on health related quality of life in Rio de Janeiro. Lepr Rev. 2017;88:499-509.

62. Bower B, Butlin C, Alam K, Lockwood D, Walker S. Health-Related Quality of Life amongst people affected by Erythema Nodosum Leprosum in Bangladesh: a Cross Sectional Study. Lepr Rev. 2017;88:488-98.

63. Borges-de-Oliveira R, Rocha-Leite Cl, Araujo-de-Freitas L, Queiroz DA, Machado PR, Quarantini LC. Perception of social exclusion, neuropathy, and quality of life among Hansen's disease patients. Int J Psychiatry Med. 2015;49(3):176-86. 
64. Do Prado GD, Ruiz Prado RB, Camargo Marciano LHS, Tonelli Nardi SM, Cordeiro JA, Monteiro HL. WHO disability grade does not influence physical activity in Brazilian leprosy patients. Lepr Rev. 2011;82(3):270-8.

65. Sousa NP, Silva MIB, Lobo CG, Barboza MCC, Abdon APV. Análise da qualidade de vida em pacientes com incapacidades funcionais decorrentes de hanseníase. Hansenologia Internacionalis. 2011;36(1):11-6.

66. Darlong J, Govindharaj P, Mahato B, Lockwood DN, Walker SL. Health-related quality of life associated with erythema nodosum leprosum in Purulia, West Bengal, India. Lepr Rev. 2020;(91):100-7.

67. Lima JMPF, Batista DM, Riberio Neto CD, Carvalhal MFN. Avaliação da qualidade de vida de pacientes hansênicos: uma abordagem quantitativa. Rev Neuro Psiq. 2019;23(1):14-26.

68. Budel AR, Raymundo AR, Costa CF, Gerhardt C, Pedri LE. Perfil dos pacientes acometidos pela hanseníase atendidos no Ambulatório de Dermatologia do Hospital Evangélico de Curitiba. An Bras Dermatol. 2011;86(5):942-46.

69. Hunt WTN, Hùng NT, Tru'ò'ng NN, Nikolaou V, Duy Đăng Khoa N, Hồng Ly T. A case-control study comparing the Dermatology Life Quality Index (DLQI) ratings of patients undergoing leprosy treatment, people cured of leprosy, and controls in Vietnam. Lepr Rev. 2018;89:46-55.

70. Proto PS, Machado Filho CDS, Rehder JRCL, Paixão MP, Angelucci RI. Qualidade de vida em hanseníase: análise comparativa entre pacientes da região Amazônica com pacientes da região do ABC, São Paulo, Brasil. An Bras Dermatol. 2010;85(6):939-41.

71. An JG, Ma JH, Xiao SX, Xiao SB, Yang F. Quality of life in patients with lepromatous leprosy in China. J Eur Acad Dermatol Venereol. 2010;24(7):827-32.

72. Castro RNC, Veloso TC, Filho LJSM, Coelho LC, Pinto LB, Castro AMNC. Avaliação do grau de incapacidade física de pacientes com hanseníase submetidos ao Dermatology Quality Life Index em centro de referência e unidades básicas de saúde de São Luis, MA. Rev Bras Clin Med. 2009;7:390-2.

73. Yap F, Kiung S, Yap J. Quality of life in patients with erythema nodosum leprosum in Kuala Lumpur, Malaysia. Indian Dermatology Online Journal. 2016;7(4):255.

74. Fortunato CN, Silva ACO, Mendes MS, Silva Júnior SV, Silva AB, Freire MEM. Calidad de vida de las personas con enfermedad de Hansen asistidas en un hospital de referencia, Paraíba-Brasil. Enferm glob. 2019;18(56):119-58.

75. Singhal AK, De A, Reja AHH, Aggarwal I, Sharma N, Ansari A, et al. The Impact of Fixed Duration Multidrug Therapy on the Host and the Agent: A Pilot Study Using Clinical, Bacteriological, and Quality of Life Assessment Tools. Indian J Dermatol. 2018;63(6):524-6.

76. Das NK, De A, Naskar B, Sil A, Das S, Sarda A, et al. A Quality of Life Study of Patients with Leprosy Attending the Dermatology OPD of a Tertiary Care Center of Eastern India. Indian J Dermatol. 2020;65(1):42-6.

77. Solanki AD, Barot JP, Patel JH, Patel NM, Patel D, Nagrani N, et al. Measurement of Quality of Life in patients of Leprosy attending Outdoor Patient Department at Tertiary Care Center of Ahmedabad: A Cross Sectional Study. Indian J Lepr. 2020;(92):139-45.

78. Bottene IMC, Reis VMS. Quality of life of patients with paucibacillary leprosy. An Bras Dermatol. 2012;87(3):408-11.

79. Guimenes Albuquerque R, Grüdtner Buratto G, Hirotsu C, Maeda SM, Floriano MC, Andersen ML, et al. Comparison of quality of life evaluated by SF-36 and DLQI in multibacillary and paucibacillary leprosy patients from Sao Paulo, Brazil. Int J Dermatol. 2019;58(12):1415-22.

80. Neder L, Weelden M, Viola GR, Lourenço DM, Len CA, Silva CA. Qualidade de vida relacionada à saúde avaliada pelo Inventário Pediátrico de Qualidade de Vida 4.0 em pacientes pediátricos com hanseníase e manifestações musculoesqueléticas. Adv Rheumatol. 2015;55(5):414-9.

81. Benedicto CB, Marques TT, Milanp AP, Galan NGA, Nardi ST, Duerksen F, et al. Avaliação da qualidade de vida, grau de incapacidade e do desenho da figura humana em pacientes com neuropatias na hanseníase. Acta Fisiátrica. 2017;24(3):120-6.

82. Loiola HAB, Aquino DMC, Cardoso LSP, Paiva MFL, Coutinho NPS, Dias RS. Perfil epidemiológico, clínico e qualidade de vida de crianças com hanseníase em um município hiperendêmico. Revista Enfermagem UERJ. 2018;(26):e32251. DOI: https://doi.org/10.12957/ reuerj.2018.32251.

83. Palo SK, Swain S, Roul S, Priyadarshini S, Pati S. Improvement in quality of life after reconstructive surgery among leprosy affected persons - a preoperative and postoperative comparison in Mayurbhanj District of Odisha, India. Indian J Lepr. 2019;91:303-13.

84. Wan EL, Noboa J, Baltodano PA, Jousin RM, Ericson WB, Wilton JP. Nerve decompression for leprous neuropathy: A prospective study from Ecuador. Lepr Rev 2017;88:95-108.

85. Bello Al, Denfzee SA, lyor F. Health related quality of life amongst people affected by leprosy in South Ghana: A needs assessment. Lepr Rev. 2013;84:(1)76-84.

86. Garbin CAS, Garbin AJl, Carloni MEOG, Rovida TAS, Martins RJ. The stigma and prejudice of leprosy: influence on the human condition. Rev Soc Bras Med Trop. 2015;48(2):194-201.

87. Eyanoer PC. Social acceptance and quality of life of leprosy patient. IOP Conf. Series: Earth and Environmental Science. 2018;125:012100. DOI: https://doi.org/10.1088/1755-1315/125/1/012100.

88. Haraldstad K, Wahl A, Andenæs R, Andersen JR, Andersen MH, Beisland E, et al. A systematic review of quality of life research in medicine and health sciences. Qual Life Res. 2019;28(10):2641-50.

89. Brasil. Ministério da Saúde. Estratégia Nacional para o Enfrentamento da Hanseníase - 2019-2022 [Internet]. Brasília; 2019. [cited 2020 May 20]. Available from: http://www.aids.gov.br/pt-br/pub/2020/estrategia-nacional-para-enfrentamento-da-hanseniase-2019-2022.

90. Minayo MCS, Hartz ZMA, Buss PM. Qualidade de vida e saúde: um debate necessário. Ciênc saúde coletiva [Internet]. 2000 [cited 2021 Mar 13];5(1):7-18. Available from: http://www.scielo.br/scielo.php?script=sci_arttext\&pid=S1413-81232000000100002\&lng=en. 
91. Pereira EF, Teixeira CS, Santos A. Qualidade de vida: abordagens, conceitos e avaliação. Rev bras educ fís esporte [Internet]. 2012 [cited 2021 Mar 13];26(2):241-50. Available from: http://www.scielo.br/scielo.php?script=sci_arttext\&pid=S1807$55092012000200007 \& \operatorname{lng}=\mathrm{en}$.

92. Brasil. Ministério da Saúde. Caderneta de saúde da pessoa acometida pela hanseníase [Internet]. Brasília; 2020 [cited 2020 May 20]. Available from: http://www.aids.gov.br/pt-br/pub/2021/caderneta-de-saude-da-pessoa-acometida-pela-hanseniase.

93. Pascoal C, Brasil S, Francisco R, Marques-Da-Silva D, Rafalko A, Jaeken J, et al. Patient and observer reported outcome measures to evaluate health-related quality of life in inherited metabolic diseases: a scoping review. Orphan J Rare Dis. 2018;13(1):215.

94. Kini SP, DeLong LK. Overview of health status quality-oflife measures. Dermatol Clin. 2012;30(2):209-21.

95. Soares AHR, Martins AJ, Lopes MCB, Britto JAA, Oliveira CQ, Moreira MCN. Qualidade de vida de crianças e adolescentes: uma revisão bibliográfica. Ciênc saúde coletiva. 2011;16(7):3197-3206.

96. World Health Organization. Global leprosy strategy 2016-2020. New Delhi: WHO; 2016.

97. Freitas BHBM, Cortela DCB, Ferreira SMB. Trend of leprosy in individuals under the age of 15 in Mato Grosso (Brazil), $2001-2013$. Rev Saúde Pública [Internet]. 2017 [cited 2021 Mar 13];51:28. Available from: http://www.scielo.br/scielo.php?script=sci_arttext\&pid= S0034-89102017000100226\&lng=en.

98. Melo Matos EV, Ferreira AMR, Palmeira IP, Santos WN, Silva RAR. Hanseníase em menores de quinze anos: uma revisão integrativa da literatura. Revista Prevenção de Infecção e Saúde. 2015;1(4):63.

99. Rodrigues TSV, Gomes LC, Cortela DB, Silva EI, Silva CAL, Ferreira SMB. Factors associated with leprosy in children contacts of notified adults in an endemic region of Midwest Brazil. J Pediatr (Rio J) [Internet]. 2020 [cited 2021 Mar 13];96(5):593-9. Available from: http:// www.scielo.br/scielo.php?script=sci_arttext\&pid=S0021-75572020000500593\&lng=en.

100. Fleck MPA, Leal OF, Louzada S, Xavier M, Chachamovich E, Vieira G, et al. Desenvolvimento da versão em português do instrumento de avaliação de qualidade de vida da OMS (WHOQOL-100). Rev Bras Psiquiatr [Internet]. 1999 [cited 2021 Mar 13];21(1):19-28. Dispónível em: http://www.scielo.br/scielo.php?script=sci_arttext\&pid=S1516-44461999000100006\&lng=en.

101. Finlay AY, Khan GK. Dermatology life quality index (DLQI)-a simple practical measure for routine clinical use. Clin Exp Dermatol. 1994;19:210-6. 